\title{
Chronic Postbronchiolitis Airway Instability Induced with Anti-IFN- $\gamma$ Antibody in F344 Rats
}

\author{
RONALD L. SORKNESS, WILLIAM L. CASTLEMAN, LANCE D. MIKUS, ANNE G. MOSSER, AND \\ ROBERT F. LEMANSKE, JR. \\ Division of Allergy and Immunology, Departments of Medicine and Pediatrics, University of Wisconsin, \\ Madison, Wisconsin 53792, U.S.A. [R.L.S., L.D.M., A.G.M., R.F.L.]; School of Pharmacy, University of \\ Wisconsin, Madison, Wisconsin 53705, U.S.A. [R.L.S.]; and Department of Pathobiology, University of \\ Florida, Gainesville, Florida 32611, U.S.A. [W.L.C.]
}

ABSTRACT

\begin{abstract}
Analogous to childhood-onset asthma in humans, rats may develop a chronic asthmalike phenotype, depending on their genetic background and the age at which they experience a viral airway injury. Brown Norway rats develop a postbronchiolitis asthmalike phenotype that may be prevented with supplements of interferon- $\gamma($ IFN- $\gamma)$; we hypothesized that the normally resistant F344 rat strain would develop the asthmalike phenotype if the IFN- $\gamma$ response were suppressed during viral illness. Weanling F344 rats were pretreated with anti-IFN- $\gamma$ or control antibody, and inoculated with Sendai virus or vehicle. Anti-IFN- $\gamma$ treatment reduced lung IFN- $\gamma$ and increased IL-4 mRNA during the infection. Physiologic studies performed 8 wk later revealed premature airway closure $(p=0.03)$ and elevated specific pulmonary resistance $(p<0.01)$ in the postbronchiolitis anti-IFN- $\gamma$ group compared with noninfected controls and untreated postbronchiolitis rats. However, unlike the postbronchiolitis asthmalike phenotype in Brown Norway rats, bronchiolar inflammation and fibrosis were absent in the F344 rats. Lung elastic recoil and alveolar surface density also were unchanged compared with noninfected control rats. We conclude that there is an interactive
\end{abstract}

effect of a weak IFN- $\gamma$ response and viral bronchiolitis at an early age that may result in persistent postbronchiolitis airway dysfunction. The presence of premature airway closure that is independent of airway wall inflammation or changes in lung elastic recoil suggests peripheral airway instability as a mechanism for the airway obstruction. (Pediatr Res 52: 382-386, 2002)

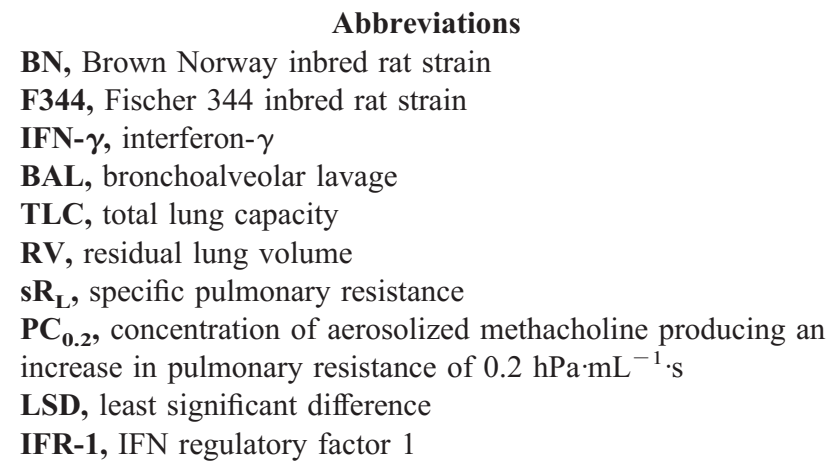

Recent observations have indicated that asthma developing in the first decade of life may have its inception during infancy (1). Both genetic or host (atopy) and environmental (allergens, viruses) factors have been implicated in asthma pathogenesis, but their relative importance either alone, or in combination, has yet to be established. To study the contribution of, and the interactions among, age (development), patterns of cytokine secretion, and virus infections on the subsequent development of asthma, we have developed an animal model that exhibits many of these characteristics (2-5).

Received November 30, 2001; accepted April 15, 2002.

Correspondence and reprint requests: Ronald L. Sorkness, Ph.D., Morris Institute for Respiratory Research, K4-949 Clinical Science Center-9988, 600 Highland Avenue, Madison, WI 53792, U.S.A.; e-mail: RLSORKNE@facstaff.wisc.edu

Supported by NIH grants AI-34891 and HL-56396.

DOI: 10.1203/01.PDR.0000025345.35944.85
We have observed that parainfluenza type 1 (Sendai) virus infections have different long-term outcomes when they occur in $\mathrm{BN}$ versus $\mathrm{F} 344$ strains of rats. In the BN strain, known to be a high IgE antibody responder and Th2-skewed, Sendai virus infection at 3-4 wk of age leads to the development of an asthmalike phenotype, characterized by chronic bronchiolar inflammation and remodeling (5), and airway dysfunction, including methacholine hyperresponsiveness (5) and episodic increases in pulmonary resistance that are attenuated with corticosteroid treatment (2). In contrast to the BN strain, the F344 strain (Th1-skewed) has similar pulmonary histologic features within the first 10-14 d after infection, but does not go on to develop any of the features characteristic of the asthmatic phenotype once this initial inflammatory response has resolved (5). The development of the asthmalike phenotype appears to be related to cytokine response patterns during infection, as evidenced by the relatively weaker IFN- $\gamma$ responses in $\mathrm{BN}$ rats 
(3) and by the prevention of the development of the asthmalike phenotype when $\mathrm{BN}$ rats receive IFN- $\gamma$ supplements during viral infection (4). We therefore hypothesized that the IFN- $\gamma$ response during viral bronchiolitis is a determining factor for the development of the asthmalike phenotype, and designed the current study to test whether treating the normally resistant F344 rats with an anti-IFN- $\gamma$ antibody during viral infection would result in the development of postbronchiolitis airway sequelae.

\section{METHODS}

All procedures were approved by the Animal Care and Use Committee. Electronic identification implants were placed in all rats, and the random identification number was used for all data acquisition so that the investigators were blinded with respect to the treatment group assignments. Weanling (age 3-4 wk) male inbred F344 rats (Charles River Laboratories, Raleigh, NC, U.S.A.) were injected i.p. with a single dose of 0.2 $\mathrm{mg}$ of murine anti-rat IFN- $\gamma$ neutralizing MAb (clone DB-1; Biosource International, Camarillo, CA, U.S.A.); this dose was selected after preliminary studies showing no additional depression of BAL fluid IFN- $\gamma$ with a dose of $0.4 \mathrm{mg}$. Controls for the antibody treatment were an isotype-matched murine antibody (Chemicon International, Temecula, CA, U.S.A.) or sterile PBS, to detect any nonspecific antibody effects. One day after the injection, the rats were inoculated with either aerosolized parainfluenza type 1 (Sendai) virus or sterile vehicle, using an aerosol exposure apparatus as described previously (4). For studies during the acute viral illness, rats were euthanized (urethane $1.5 \mathrm{~g} / \mathrm{kg}$ i.p. and exsanguination) at postinoculation $\mathrm{d} 3,5$, or 7 . In some rats, whole-lung BAL was performed to obtain leukocyte counts (4) and IFN- $\gamma$ content (3). Other rats were euthanized and their lungs were frozen in liquid nitrogen and used for quantification of lung viral titers by plaque assay (6) and of lung IL-4 mRNA by competitive reverse transcription-PCR (4). Rats were weighed daily during the first week of studies.

The remaining rats were evaluated for pulmonary physiology at wk 8 and 11 after inoculation. After sedation with pentobarbital $45 \mathrm{mg} / \mathrm{kg}$ i.p., an orotracheal tube (PE205, $5 \mathrm{~cm}$ ) and a water-filled esophageal pressure monitor were placed atraumatically, and pulmonary resistance was measured using a total body plethysmograph (4). At wk 8 , deflation quasi-static lung pressure-volume curves were generated by inflating the lungs to $30 \mathrm{hPa}$ transpulmonary pressure, then deflating the lungs over a 5-10 s period of time while recording the plethysmograph volume signal and the esophageal-tracheal differential pressure signal. Volume versus pressure data obtained before the first inspiratory effort (typically from $+30 \mathrm{hPa}$ to $+4 \mathrm{hPa}$ ) were used for analysis. Thoracic gas volume was measured by the Boyle's law method at end-expiration (7), followed by inflation with a syringe to $30 \mathrm{hPa}$ to determine TLC, and deflation over a $1-2 \mathrm{~s}$ period of time to $-30 \mathrm{hPa}$ to determine vital capacity and RV. ${ }_{\mathrm{s}} \mathrm{RL}$ was computed for each rat as the product of pulmonary resistance and thoracic gas volume. At wk 11, airway responsiveness to aerosolized methacholine was assessed by administering doubling concen- trations $(1-32 \mathrm{mM})$ of the agonist as 10 breaths of $2.5-\mathrm{mL}$ tidal volume, using an ultrasonic nebulizer in series with a ventilator (5), and recording the maximum change in pulmonary resistance. Methacholine responsiveness was computed as the log molar concentration associated with an increase in pulmonary resistance of $0.2 \mathrm{hPa} \cdot \mathrm{mL}^{-1} \cdot \mathrm{s}\left(\mathrm{PC}_{0.2}\right)(5)$. At wk 12, the rats were euthanized, and their lungs were fixed by inflating to $25 \mathrm{hPa}$ with $4 \%$ paraformaldehyde fixative. Paraffin sections of lung were prepared and evaluated by a pathologist in a blinded manner for the proportion of airways having inflammatory cells or bronchiolar wall thickening (4). Alveolar surface density was estimated using a simplified morphometric method on paraffin sections (8).

Data were analyzed with SYSTAT v.10 software (SPSS, Chicago, IL, U.S.A.), using multiple general linear hypothesis ANOVA methods, and Fisher's LSD test for planned pairwise comparisons with data or log-transformed data that conformed to parametric assumptions. Kruskal-Wallis or Mann-Whitney $U$ tests were used for data that did not conform to assumptions for parametric analyses.

\section{RESULTS}

Week 1 after inoculation. Figure 1 summarizes the amounts of IFN- $\gamma$ recovered with whole lung BAL at 3,5, and $7 \mathrm{~d}$ after inoculation with Sendai virus. Small amounts of IFN- $\gamma$ were present in most of the lungs at $\mathrm{d} 3$, and by d 5 nanogram quantities were recovered from the rats not treated with the anti-IFN- $\gamma$ MAb, compared with quantities more than an order of magnitude smaller in the rats pretreated with anti-IFN- $\gamma$ MAb. At d 7, BAL IFN- $\gamma$ was declining in both groups, with persistence of the difference between the anti-IFN- $\gamma$ and control groups. In noninfected rats $(n=10)$, BAL IFN- $\gamma$ was $<20$ pg/lung.

IL-4 mRNA, measured in lung homogenates by competitive reverse transcription-PCR, was significantly more abundant ( $p$ $=0.04$, Mann-Whitney $U$ test) at $\mathrm{d} 3$ after Sendai virus

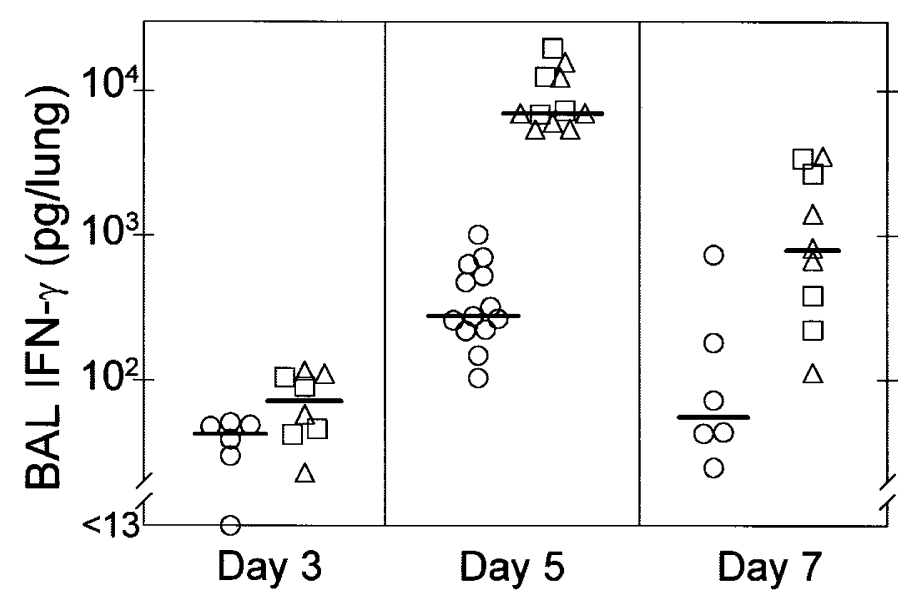

Figure 1. IFN- $\gamma$ obtained in BAL fluid from rats at 3, 5, and $7 \mathrm{~d}$ after inoculation with Sendai virus. Rats pretreated with anti-IFN- $\gamma$ antibody (O) had significantly less BAL IFN- $\gamma$ compared with the group treated with either control antibody $(\triangle)$ or PBS $(\square)$ at d 5 ( $p<0.0001$, Mann-Whitney $U$ test) and at $\mathrm{d} 7(p=0.01)$; treatment groups were not significantly different at $\mathrm{d} 3(p=$ $0.09)$. Each symbol represents one rat; bars indicate group medians. IFN- $\gamma$ was $<20 \mathrm{pg} / \mathrm{lung}$ in BAL of noninfected rats $(n=10)$. 
inoculation in rats pretreated with anti-IFN- $\gamma \operatorname{MAb}(n=6$, median, $0.5 \mathrm{fg}$ competitive fragments) compared with those pretreated with control antibody $(n=6$, median, $0.1 \mathrm{fg}$ competitive fragments); at d 7 after inoculation, both treatment groups had low abundance of IL-4 mRNA, with no significant group differences.

Global indicators of severity for the acute viral illness (lung viral titers, growth retardation, BAL leukocytes) were similar for virus-infected rats of both treatment groups. Lung viral titers were similar at 3 and $5 \mathrm{~d}$ after inoculation, averaging $10^{7}$ plaque-forming units per gram of lung in both anti-IFN- $\gamma$ Mab-treated rats $(n=10)$ and rats treated with either control antibody or PBS $(n=14)$. At d 7, lung viral titers had fallen to below detectable range in four of six rats from each of the treatment groups (anti-IFN- $\gamma$ and control antibody), indicating that viral clearance also was not affected by anti-IFN- $\gamma$ MAb treatment. Body weight gain was retarded during postinoculation d 3-5 in the infected rats $(n=116)$ compared with the noninfected rats $(n=22 ; p<0.0001$, repeated measures ANOVA), but weight gain was not altered by treatment with anti-IFN- $\gamma$ MAb. Compared with noninfected rats $(n=10)$, the virus-infected rats had elevated BAL total leukocyte counts on d $5(n=24, p<0.0001$, ANOVA $)$ and $7(n=15, p<$ $0.0001)$, but this was not changed significantly on $\mathrm{d} 3(n=14)$; BAL leukocytes were not altered significantly by treatment with anti-IFN- $\gamma$ MAb.

Weeks 8-12 after inoculation. There were no significant differences among groups with respect to body weight at 8-12 wk after inoculation. Examination of lung sections harvested in postinoculation wk 12 revealed no significant virus- or antibody treatment-associated bronchiolar inflammatory cell infiltration or bronchiolar wall thickening (Fig. 2). However, the postbronchiolitis rats that had been treated with anti-IFN- $\gamma$ MAb exhibited abnormal airway physiology, having significantly higher $\mathrm{sR}_{\mathrm{L}}$ (Fig. 3) and premature airway closure,

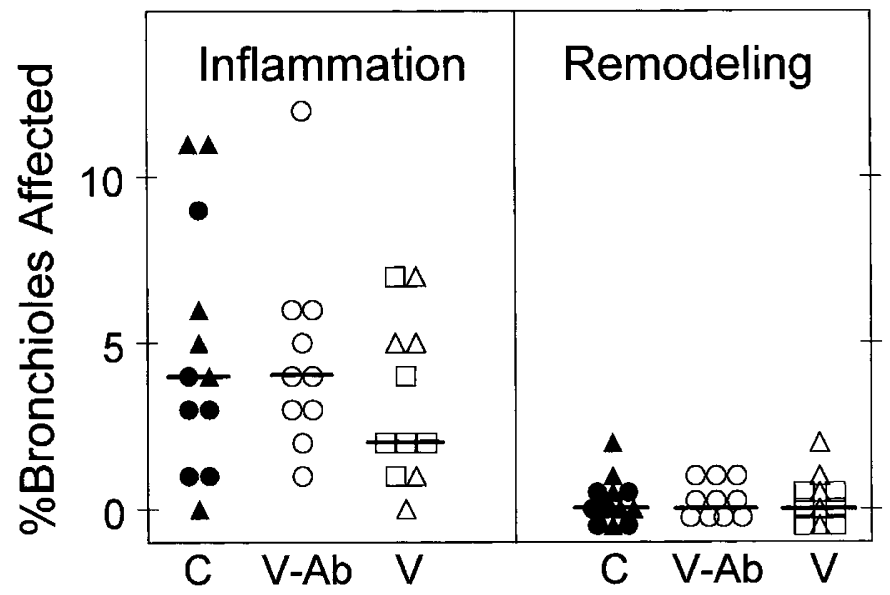

Figure 2. Prevalence of bronchioles having more than five inflammatory cells in the wall (inflammation) or increased wall thickness as a result of extracellular matrix (remodeling) at $12 \mathrm{wk}$ after inoculation. Circles indicate pretreatment with anti-IFN- $\gamma$ antibody; triangles indicate pretreatment with control antibody; squares indicate pretreatment with PBS; bars indicate group medians. No significant differences among noninfected rats $(C)$, postviral rats pretreated with anti-IFN- $\gamma$ antibody $(V-A b)$, and postviral rats pretreated with either control antibody or PBS $(V)$ were seen.

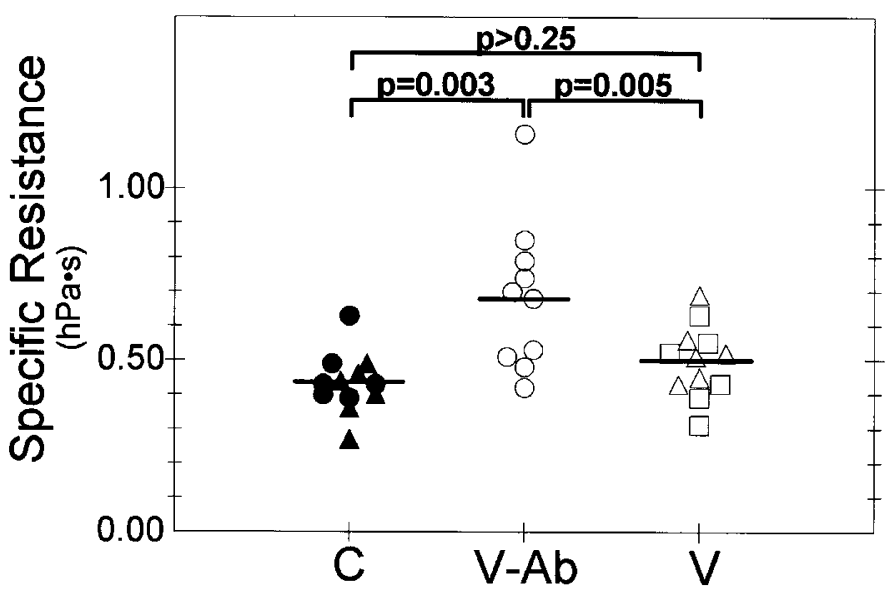

Figure 3. Specific pulmonary resistance at $8 \mathrm{wk}$ after inoculation. Noninfected rats $(C)$, postviral rats pretreated with anti-IFN- $\gamma$ antibody $(V-A b)$, and postviral rats pretreated with either control antibody or PBS $(V)$. Circles indicate pretreatment with anti-IFN- $\gamma$ antibody; triangles indicate pretreatment with control antibody; squares indicate pretreatment with PBS; bars indicate group means. Probability values are results of group comparisons using ANOVA with Fisher's LSD test.

detected as elevated RV/TLC (Fig. 4), compared both with noninfected rats and with postbronchiolitis rats that did not receive anti-IFN- $\gamma$ MAb. The postbronchiolitis rats treated with anti-IFN- $\gamma$ MAb had equivocal changes in methacholine responsiveness, the median $\mathrm{PC}_{0.2}$ being reduced by less than one doubling concentration compared with noninfected controls ( $p=0.001$, Mann-Whitney $U$ test), and not significantly different compared with postbronchiolitis rats not treated with the antibody. The methacholine $\mathrm{PC}_{0.2}$ also was not significantly different between the postbronchiolitis rats not treated with the antibody and the noninfected controls. The postbronchiolitis rats of the anti-IFN- $\gamma$ MAb treatment group also had slightly larger TLC relative to body weight $(11.4 \pm 0.17 \mathrm{~mL}$; least squares mean $\pm \mathrm{SEM}$, analysis of covariance, using

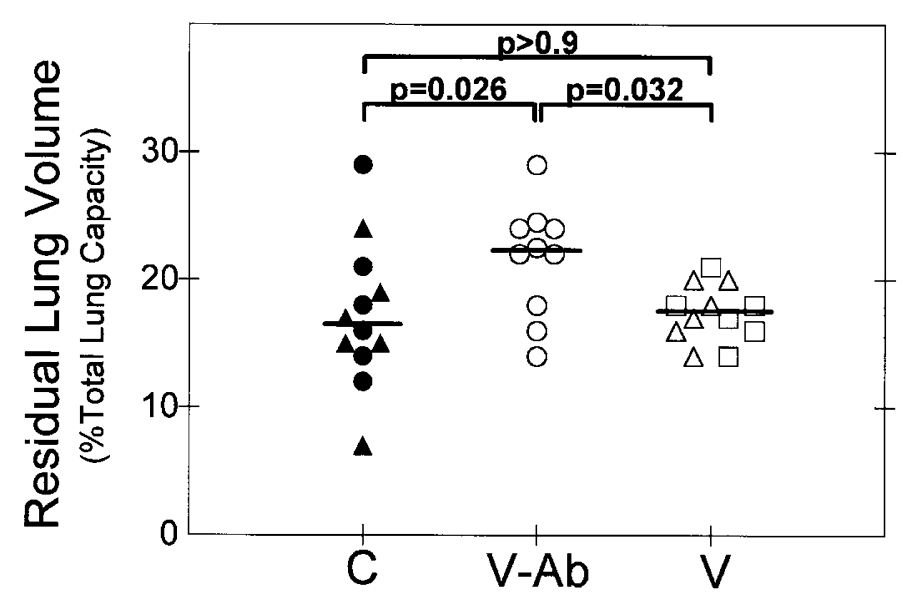

Figure 4. RV as percentage of TLC at $8 \mathrm{wk}$ after inoculation. Noninfected rats $(C)$, postviral rats pretreated with anti-IFN- $\gamma$ antibody $(V-A b)$, and postviral rats pretreated with either control antibody or PBS $(V)$. Circles indicate pretreatment with anti-IFN- $\gamma$ antibody; triangles indicate pretreatment with control antibody; squares indicate pretreatment with PBS; bars indicate group medians. Probability values are results of group comparisons using ANOVA with Fisher's LSD test. 
weight as the covariate; $n=10$ ) compared with noninfected rats $(10.6 \pm 0.16 \mathrm{~mL}, n=12 ; p<0.001)$ and with postviral rats not treated with anti-IFN- $\gamma$ MAb $(10.8 \pm 0.16 \mathrm{~mL}, n=$ $12 ; p=0.01)$.

To determine whether abnormalities in airway physiology and lung volume were associated with altered lung parenchyma, studies of lung elastic recoil and alveolar surface density were completed. Deflation quasi-static pressurevolume curves revealed that lung elastic recoil as a proportion of TLC was not different among the treatment groups (Fig. 5). The alveolar surface density in lungs of the postviral rats treated with anti-IFN- $\gamma$ MAb (mean \pm SD, $765 \pm 147 \mathrm{~cm}^{2}$ alveolar surface per $\mathrm{cm}^{3}$ lung volume, $n=8$ ) was not significantly different from that of noninfected rats $(807 \pm 99$ $\mathrm{cm}^{2} / \mathrm{cm}^{3}, n=9$ ) or of postviral rats treated with either control antibody or PBS $\left(816 \pm 156 \mathrm{~cm}^{2} / \mathrm{cm}^{3}, n=7\right)$.

\section{DISCUSSION}

The results of these studies demonstrate that suppression of IFN- $\gamma$ during acute viral bronchiolitis in young F344 rats induces chronic postbronchiolitis airway dysfunction, in contrast to untreated F344 rats that recover from viral bronchiolitis without significant airway abnormalities. This finding supports the hypothesis that the IFN- $\gamma$ response during acute viral illness is important to the ultimate recovery from viral airway injury, and complements our previous studies showing that the F344 and BN rat strains differ in their ability to produce IFN- $\gamma$ (3), and that postbronchiolitis airway dysfunction can be prevented in $\mathrm{BN}$ rats by supplementing IFN- $\gamma$ early in the course of the viral illness (4).

Treatment of F344 rats with anti-IFN- $\gamma$ MAb resulted in a reduction of BAL IFN- $\gamma$ to levels similar to those present in weanling $\mathrm{BN}$ rats during viral bronchiolitis (3). Alteration of IFN- $\gamma$ during viral illness resulted in modulation of IFN- $\gamma$ dependent processes, as detected by changes in the expression of lung IL-4 mRNA in both anti-IFN- $\gamma$ MAb-treated F344 rats

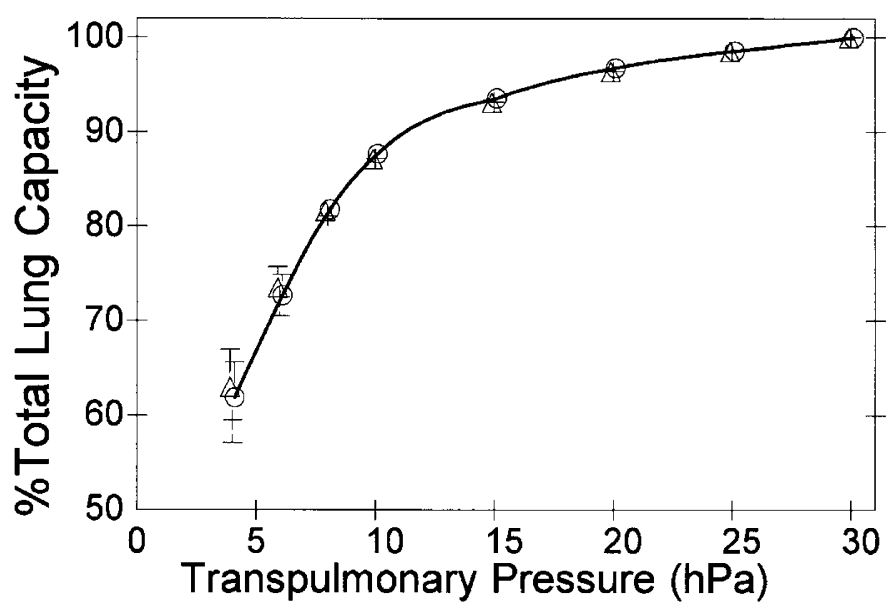

Figure 5. Deflation quasi-static pressure-volume curves measured at $8 \mathrm{wk}$ after inoculation. Noninfected rats $(+)$, postviral rats pretreated with antiIFN- $\gamma$ antibody $(O)$, and postviral rats pretreated with either control antibody or PBS $(\triangle)$. Each symbol is the mean \pm SEM for $10-12$ rats. There were no significant differences among the groups for the range of transpulmonary pressures from 4 to $30 \mathrm{hPa}$. (present study) and IFN- $\gamma$-supplemented BN rats (4), but this degree of IFN- $\gamma$ modulation did not alter the severity of the viral illness (viral titers, BAL leukocyte numbers, growth retardation) or the postrecovery growth in either strain. Thus, the postbronchiolitis consequences of manipulating IFN- $\gamma$ during viral bronchiolitis cannot be attributed to artifacts of altered severity of the illness or altered adult body size.

The anti-IFN- $\gamma$ MAb-treated postbronchiolitis F344 rats exhibited abnormal airway physiology, with elevated $\mathrm{sR}_{\mathrm{L}}$ and premature airway closure (Figs. 3 and 4), analogous to the postbronchiolitis airway dysfunction of $\mathrm{BN}$ rats $(2,4,5,9)$. Premature airway closure indicates an imbalance in the coupling between bronchioles and lung parenchyma that normally stabilizes membranous airways, and the prominent finding of premature airway closure in the treated F344 rats therefore suggests that their postbronchiolitis airway obstruction may be caused by an imbalance in the forces that maintain airway patency, resulting in peripheral airway instability and closure. We reasoned that airway narrowing and closure might be associated with a loss of lung elastic recoil, as a result of intrinsic elastic changes in lung parenchyma (10) or alveolar wall destruction (11). However, there were no detectable shifts in the lung pressure-volume curve (Fig. 5), and no significant differences in alveolar surface density, making the reduced elastic recoil mechanism an unlikely explanation for the airway dysfunction in the F344 rats. By exclusion, we therefore propose that the F344 rats with postbronchiolitis airway dysfunction have peripheral airway instability, possibly associated with altered airway smooth muscle dynamics (12), reduced airway surfactant function (13), or altered airway neural controls (14). Peripheral airway closure is being recognized as a potentially important contribution to severe airway obstruction in asthma $(15,16)$, and thus identification of factors that contribute to airway instability and closure is valuable to our understanding of airway obstruction.

In contrast to these parallels with $\mathrm{BN}$ rats, the anti-IFN- $\gamma$ $\mathrm{MAb}$-treated F344 rats did not exhibit the prominent airway inflammation, remodeling, and hyperresponsiveness that are typical of BN rats after bronchiolitis (4, 5). This was an unexpected finding, in that our previous studies of postbronchiolitis airway abnormalities in rats showed associations between physiologic and morphologic abnormalities among the various treatment groups. Instead, the results of the current study suggest that there also may be postbronchiolitis alterations in airways that are independent of a chronic inflammatory process, but that perhaps interact with an inflammatory process to cause the episodic, glucocorticoid-sensitive exacerbations of airway obstruction (2) that are present in the postbronchiolitis BN rats. The lack of a prominent hyperresponsiveness to methacholine in the F344 rats may be explained by the lack of an inflammatory process in the central airways, along with a peripheral airway location of the obstruction, to which measurements of total pulmonary resistance are relatively insensitive. Possible explanations for why the anti-IFN- $\gamma$ $\mathrm{MAb}$-treated F344 rats did not develop chronic airway inflammation are that the IFN- $\gamma$ activity remained adequate to prevent the events leading to chronic postbronchiolitis inflammation, or that F344 rats have more-robust homeostasis 
mechanisms that can overcome the imbalances initiated by the transient IFN- $\gamma$ insufficiency.

Several morphologic approaches have been undertaken to characterize alterations in airway growth and remodeling that occur after Sendai virus infection in inbred and outbred rats. When neonatal CD-strain and $\mathrm{BN}$ rats in the proliferative stage of postnatal lung growth are infected with Sendai virus at $5 \mathrm{~d}$ of age, they develop severe bronchiolar hypoplasia characterized by bronchiolar narrowing that is detectable in airway corrosion casts and by increased airway wall thickness $(5,17)$. Weanling BN rats inoculated at $25 \mathrm{~d}$ of age are resistant to Sendai virus-induced airway hypoplasia, and do not develop narrowed airways that can be detected in corrosion casts; however, weanling BN rats are still susceptible to bronchiolar wall remodeling characterized by increased airway wall thickness and fibrosis $(5,18)$. In contrast, F344 rats develop neither bronchiolar hypoplasia nor airway wall remodeling characterized by airway wall thickening when infected with Sendai virus, even as neonates. The airway wall thickening in $\mathrm{BN}$ rats is associated with persistent airway wall infiltration by mononuclear inflammatory cells (lymphocytes and macrophages) and by mast cells. Furthermore, there is accumulation of collagen in matrix in the wall that is detectable by both histochemical and morphometric techniques (5). Increased fibroblast proliferation in airways has been detected in weanling BN rats after Sendai virus infection by bromodeoxyuridine incorporation (18). Airway smooth muscle hypertrophy or hyperplasia has not been detected as a feature of postbronchiolitis airway remodeling in $\mathrm{BN}$ rats (unpublished data). None of these characteristic features of postbronchiolitis airway remodeling was apparent in the F344 rats that were treated with anti-IFN- $\gamma$ MAb in the present study.

The significance of this rat model of the induction of airway dysfunction after viral bronchiolitis is underscored by a number of parallel observations in humans associating dysregulation of IFN- $\gamma$ secretion with atopy, asthma, and the clinical response to viral infections in infancy and early childhood (1, 19). Interferon- $\gamma$ exerts its biologic effects through its binding to the cell surface-ligand-binding chain IFN- $\gamma$ receptor 1 in combination with its signaling chain, IFN- $\gamma$ receptor 2 (19). Receptor binding of IFN- $\gamma$ activates intracellular signaling pathways, which induce expression of various genes, including the IRF-1 gene (20). IRF-1 is a transcription factor that also functions as a determinant for Th1 responses (21). Recently, a significant association between IFN- $\gamma$ and IRF-1 polymorphisms with childhood atopic asthma has been observed, especially if the time of onset of asthmatic symptoms was less than $3 \mathrm{y}$ of age (19). Moreover, diminished production of IFN- $\gamma$ in both cord (22) and peripheral blood mononuclear cells $(23,24)$ has been associated with an increased prevalence of atopic disease and asthma during childhood, and an increased likelihood of developing asthma after infection with respiratory syncytial virus during infancy. Collectively, these observations indicate that genetically determined cytokine dysregulation, environmental factors such as respiratory syncytial virus infections (25), and developmental (age at time of insult, infection, exposure, or sensitization) factors may be important determinants of the inception of asthma in early life.

\section{CONCLUSION}

In conclusion, reduction of the IFN- $\gamma$ response during viral bronchiolitis in young F344 rats was associated with the development of persistent postbronchiolitis airway dysfunction. That the airway dysfunction occurred in the absence of airway wall inflammation or remodeling, and with normal lung elastic recoil, is a novel and potentially important observation relating to mechanisms of airway instability and obstructive airway disease.

\section{REFERENCES}

1. Gern JE, Lemanske Jr RF, Busse WW 1999 Early life origins of asthma. J Clin Invest 104:837-843

2. Kumar A, Sorkness RL, Kaplan MR, Lemanske Jr RF 1997 Chronic, episodic, reversible airway obstruction after viral bronchiolitis in rats. Am J Respir Crit Care Med 155:130-134

3. Mikus LD, Rosenthal LA, Sorkness RL, Lemanske Jr RF 2001 Reduced interferon- $\gamma$ secretion by natural killer cells from rats susceptible to postviral chronic airway dysfunction. Am J Respir Cell Mol Biol 24:74-82

4. Sorkness RL, Castleman WL, Kumar A, Kaplan MR, Lemanske Jr RF 1999 Prevention of chronic postbronchiolitis airway sequelae with IFN- $\gamma$ treatment in rats. Am J Respir Crit Care Med 160:705-710

5. Uhl EW, Castleman WL, Sorkness RL, Busse WW, Lemanske Jr RF, McAllister PK 1996 Parainfluenza virus-induced persistence of airway inflammation, fibrosis, and dysfunction associated with TGF- $\beta 1$ expression in Brown Norway rats. Am J Respir Crit Care Med 154:1834-1842

6. Castleman WL, Brundage-Anguish LJ, Kreitzer L, Neuenschwander SB 1987 Pathogenesis of bronchiolitis and pneumonia induced in neonatal and weanling rats by parainfluenza (Sendai) virus. Am J Pathol 129:277-286

7. Sorkness R, Clough JJ, Castleman WL, Lemanske Jr RF 1994 Virus-induced airway obstruction and parasympathetic hyperresponsiveness in adult rats. Am J Respir Crit Care Med 150:28-34

8. Weibel ER 1973 A simplified morphometric method for estimating diffusion capacity in normal and emphysematous human lungs. Am Rev Respir Dis 107:579-588

9. Sorkness RL, Tuffaha A, Lemanske Jr RF, Castleman WL 2000 Structure-function relationships in chronic post-viral airway dysfunction in rats. Am J Respir Crit Care Med 161:A274(abstr)

10. Gelb AF, Zamel N 2000 Unsuspected pseudophysiologic emphysema in chronic persistent asthma. Am J Respir Crit Care Med 162:1778-1782

11. Bellofiore S, Eidelman DH, Macklem PT, Martin JG 1989 Effects of elastase-induced emphysema on airway responsiveness to methacholine in rats. J Appl Physiol 66:606-612

12. Solway J, Fredberg JJ 1997 Perhaps airway smooth muscle dysfunction contributes to asthmatic bronchial hyperresponsiveness after all. Am J Respir Cell Mol Biol 17:144-146

13. Hohlfeld J, Fabel H, Hamm H 1997 The role of pulmonary surfactant in obstructive airways disease. Eur Respir J 10:482-491

14. Larsen GL, Colasurdo GN 1999 Neural control mechanisms within airways: disruption by respiratory syncytial virus. J Pediatr 135:21-27

15. in 't Veen CCM, Beekman AJ, Bel EH, Sterk PJ 2000 Recurrent exacerbations in severe asthma are associated with enhanced airway closure during stable episodes. Am J Respir Crit Care Med 161:1902-1906

16. Gibbons WJ, Sharma A, Lougheed D, Macklem PT 1996 Detection of excessive bronchoconstriction in asthma. Am J Respir Crit Care Med 153:582-589

17. Castleman WL, Sorkness RL, Lemanske Jr RF, Grasee G, Suyemoto MM 1988 Neonatal viral bronchiolitis and pneumonia induces bronchiolar hypoplasia and alveolar dysplasia in rats. Lab Invest 59:387-396

18. Uhl EW, Moldawer LL, Busse WW, Jack TJ, Castleman WL 1998 Increased tumor necrosis factor-alpha (TNF-alpha) gene expression in parainfluenza type 1 (Sendai) virus-induced bronchiolar fibrosis. Am J Pathol 152:513-522

19. Nakao F, Ihara K, Kusuhara K, Sasaki Y, Kinukawa N, Takabayashi A, Nishima S, Hara T 2001 Association of IFN-gamma and IFN regulatory factor 1 polymorphisms with childhood atopic asthma. J Allergy Clin Immunol 107:499-504

20. Lawless VA, Zhang S, Ozes ON, Bruns HA, Oldham I, Hoey T, Grusby MJ, Kaplan MH 2000 Stat 4 regulates multiple components of IFN- $\gamma$-inducing signaling pathways. J Immunol 165:6803-6808

21. Mamane Y, Heylbroeck C, Genin P, Algarte M, Servant MJ, LePage C, DeLuca C, Kwon H, Lin R, Hiscott J 1999 Interferon regulatory factors: the next generation. Gene 237:1-14

22. Tang MLK, Kemp AS, Thorburn J, Hill DJ 1994 Reduced interferon-gamma secretion in neonates and subsequent atopy. Lancet 344:983-985

23. Renzi PM, Turgeon JP, Marcotte JE, Drblik SP, Berube D, Gagnon MF, Spier S 1999 Reduced interferon- $\gamma$ production in infants with bronchiolitis and asthma. Am J Respir Crit Care Med 159:1417-1422

24. Martinez FD, Stern DA, Wright AL, Holberg CJ, Taussig LM, Halonen M 1995 Association of interleukin-2 and interferon-gamma production by blood mononuclear cells in infancy with parental allergy skin tests and with subsequent development of atopy. J Allergy Clin Immunol 96:652-660

25. Stein RT, Sherrill D, Morgan WJ, Holberg CJ, Halonen M, Taussig LM, Wright AL, Martinez FD 1999 Respiratory syncytial virus in early life and risk of wheeze and allergy by age 13 years. Lancet 354:541-545 